\title{
Bombesin Antagonist-Based Radioligands for Translational Nuclear Imaging of Gastrin-Releasing Peptide Receptor-Positive Tumors
}

\author{
Keelara Abiraj ${ }^{1}$, Rosalba Mansi ${ }^{1}$, Maria-Luisa Tamma ${ }^{1}$, Melpomeni Fani ${ }^{1}$, Flavio Forrer ${ }^{2}$, Guillaume Nicolas ${ }^{2}$, \\ Renzo Cescato ${ }^{3}$, Jean Claude Reubi ${ }^{3}$, and Helmut R. Maecke ${ }^{1}$ \\ ${ }^{I}$ Division of Radiological Chemistry, University Hospital Basel, Basel, Switzerland; ${ }^{2}$ Institute of Nuclear Medicine, University \\ Hospital Basel, Basel, Switzerland; and ${ }^{3}$ Division of Cell Biology and Experimental Cancer Research, Institute of Pathology, \\ University of Berne, Berne, Switzerland
}

Bombesin receptors are overexpressed on a variety of human tumors. In particular, the gastrin-releasing peptide receptor (GRPr) has been identified on prostate and breast cancers and on gastrointestinal stromal tumors. The current study aims at developing clinically translatable bombesin antagonist-based radioligands for SPECT and PET of GRPr-positive tumors. Methods: A potent bombesin antagonist (PEG $\mathrm{P}_{4} \mathrm{D}-\mathrm{Phe}-$ Gln-Trp-Ala-Val-Gly-His-Sta-Leu- $\mathrm{NH}_{2}$ [AR]) was synthesized; conjugated to the chelators DOTA, 6-carboxy-1,4,7,11-tetraazaundecane (N4), 1,4,7-triazacyclononane, 1-glutaric acid-4,7 acetic acid (NODAGA), and 4,11-bis(carboxymethyl)-1,4,8, 11-tetraazabicyclo[6.6.2] hexadecane (CB-TE2A); and radiolabeled with ${ }^{111} \mathrm{In},{ }^{99 \mathrm{mTc},}{ }^{68} \mathrm{Ga}$, and ${ }^{64} \mathrm{Cu}$, respectively. The radioconjugates were evaluated in vitro and in vivo in $\mathrm{PC}-3$ tumor-bearing nude mice. Antagonist potency was determined by $\mathrm{Ca}^{2+}$-flux measurements and immunofluorescence. Results: All the conjugates showed high binding affinity to GRPr (inhibitory concentration of $50 \%$ [ $\left.\mathrm{IC}_{50}\right], 2.5-25 \mathrm{nmol} / \mathrm{L}$ ). The immunofluorescence and $\mathrm{Ca}^{2+}$-flux assays confirmed the antagonist properties of the conjugates. Biodistribution revealed high and specific uptake in PC-3 tumor and in GRPr-positive tissues. Tumor uptake of ${ }^{64} \mathrm{Cu}-\mathrm{CB}-\mathrm{TE} 2 \mathrm{~A}-\mathrm{AR}$ (31.02 \pm 3.35 percentage injected activity per gram $[\% / \mathrm{I} / \mathrm{g}]$ ) was higher than ${ }^{99 m} \mathrm{Tc}-\mathrm{N} 4-\mathrm{AR}(24.98 \pm 5.22 \% \mathrm{IA} / \mathrm{g}),{ }^{111} \mathrm{In}-$ DOTA-AR $(10.56 \pm 0.70 \% \mathrm{IA} / \mathrm{g})$, and ${ }^{68} \mathrm{Ga}-\mathrm{NODAGA}-\mathrm{AR}$ $(7.11 \pm 3.26 \% \mathrm{IA} / \mathrm{g})$ at $1 \mathrm{~h}$ after injection. Biodistribution at later time points showed high tumor-to-background ratios because of the fast washout of the radioligand from normal organs, compared with tumor. High tumor-to-background ratios were further illustrated by PET and SPECT images of PC-3 tumor-bearing nude mice acquired at $12 \mathrm{~h}$ after injection showing high tumor uptake, clear background, and negligible or no radioactivity in the abdomen. Conclusion: The chelators do influence the affinity, antagonistic potency, and pharmacokinetics of the conjugates. The promising preclinical results warrant clinical translation of these probes for SPECT and PET.

Received Jun. 10, 2011; revision accepted Jul. 29, 2011.

For correspondence or reprints contact: Helmut R. Maecke, Department of Nuclear Medicine, University of Freiburg, Hugstetterstrasse 55, 79106 Freiburg, Germany.

E-mail: helmut.maecke@uniklinik-freiburg.de

Published online Nov. 11, 2011.

COPYRIGHT @ 2011 by the Society of Nuclear Medicine, Inc.
Key Words: prostate cancer; gastrin releasing peptide receptor; bombesin; PET/SPECT tracers

J Nucl Med 2011; 52:1970-1978

DOI: 10.2967/jnumed.111.094375

$\mathbf{P}$ eptide receptors are important targets for imaging and targeted radionuclide therapy of cancer (1-4). Receptors of the bombesin family are of particular interest because they are overexpressed on a variety of human cancers. In particular, the gastrin-releasing peptide receptor (GRPr) has been identified on prostate (5) and breast ( 6 ) cancers, on gastrointestinal stromal tumors (7), and on peritumoral vessels of ovarian cancer (8). Markwalder and Reubi (5) demonstrated GRPr expression on 30 of 30 invasive primary prostatic carcinomas with high density in most cases. Therefore, a variety of radiolabeled bombesin derivatives were developed and studied preclinically $(9-11)$ and clinically $(12,13)$. Despite some promising results, none of them seem to have provided a breakthrough in the clinic so far.

For therapeutic studies, bombesin(7-14) was conjugated to DOTA via a gly-4-aminobenzoic acid group and labeled with ${ }^{177} \mathrm{Lu}$. This compound showed promising results in preclinical models $(14,15)$ and was studied in clinical settings (phase I) (16). Side effects during a first phase I dose escalation study included abdominal cramps, diarrhea, and nausea (16). We and others hypothesized that these side effects may be absent when using bombesin-based antagonists (17-20). In addition, agonists of the bombesin family were shown to have mitogenic properties (21).

For these reasons and because we have recently shown that radiolabeled somatostatin-based antagonists have superior pharmacokinetic properties in tumor models (22), we started a program toward developing antagonistic radiovectors targeting the GRPr $(19,20)$.

In this work, we were particularly interested in performing a systematic study using the most important metallic radionuclides labeled to a potent bombesin antagonist ' $\left(\mathrm{PEG}_{4} \mathrm{D}^{\mathrm{D}}\right.$ 
Phe-Gln-Trp-Ala-Val-Gly-His-Sta-Leu-NH 2 [AR]). Metallic radionuclides may have the potential advantage of allowing for kit formulations, which may be used by the addition of radionuclide solutions. We developed conjugates for labeling with ${ }^{64} \mathrm{Cu}$ (4,11-bis(carboxymethyl)-1,4,8,11tetraazabicyclo-[6.6.2] hexadecane [CB-TE2A]-AR) and ${ }^{68} \mathrm{Ga}$ (1,4,7-triazacyclononane, 1-glutaric acid-4,7 acetic acid [NODAGA]-AR) for PET and with ${ }^{111}$ In (DOTA-AR) and ${ }^{99 \mathrm{~m}} \mathrm{Tc}$ (6-carboxy-1,4,7,11-tetraazaundecane [N4]AR) for SPECT (Fig. 1).

${ }^{64} \mathrm{Cu}$ is widely used because it can be produced easily on a medical cyclotron (23). A variety of ${ }^{64} \mathrm{Cu}$-labeled bioactive molecules, such as folate derivatives (24), antibodies (25), and peptides (26), were developed for PET studies. Past experience indicated the high importance of the use of suitable bifunctional chelators for the stable in vivo complexation of ${ }^{64} \mathrm{Cu}$ to avoid premature release of the radiometal (26). The generator-produced ${ }^{68} \mathrm{Ga}$ is attracting great interest as a metallic positron emitter for PET. ${ }^{68} \mathrm{Ga}$-labeled peptides found their way into the clinic many years ago (27) and are used successfully. ${ }^{99 \mathrm{~m}} \mathrm{Tc}$ is the workhorse of the nuclear medicine physician, and ${ }^{111} \mathrm{In}$ is being used as an important SPECT label and as a surrogate of $\beta$-emitters such as ${ }^{90} \mathrm{Y}$ and radiolanthanides.

The important outcome of this work is that antagonist potency and receptor affinity are conserved after modification with spacers and chelators, but both parameters are important determinants of overall performance. All radio-

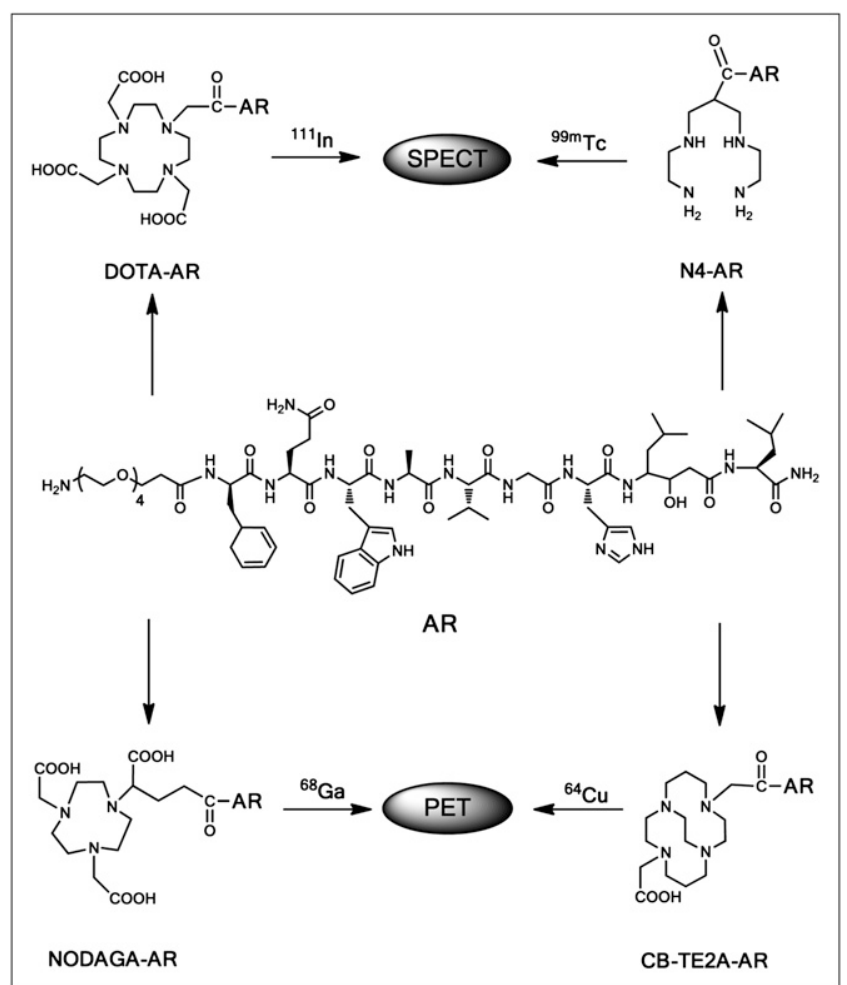

FIGURE 1. Structure of conjugates DOTA-AR, NODAGA-AR, CBTE2A-AR, and N4-AR. vectors seem to be suitable for clinical translation, offering a broad range of molecular imaging possibilities. The results encouraged us to start early clinical use in primary prostate cancer patients using ${ }^{64} \mathrm{Cu}-\mathrm{CB}-\mathrm{TE} 2 \mathrm{~A}-\mathrm{AR}$.

\section{MATERIALS AND METHODS}

The supplier information for all reagents, radionuclides, and generators and details of instruments used are provided in the supplemental data (available online only at http://jnm.snmjournals. org).

\section{Cell Lines}

Human embryonic kidney (HEK) 293 cells, stably expressing the hemagglutinine-epitope-tagged human GRPr (HEK-GRPr), were generated and cultured as previously described (17). The identity of the cells has been confirmed throughout the studies by determination of the receptor density and the growth pattern in vitro and in vivo. Human prostate cancer cells (PC-3) were obtained from American Type Culture Collection and cultured at $37^{\circ} \mathrm{C}$ and $5 \%$ $\mathrm{CO}_{2}$ either in Ham F12K or in Dulbecco modified Eagle medium containing $2 \mathrm{mM}$ L-glutamine and supplemented with $10 \%(\mathrm{v} / \mathrm{v})$ fetal bovine serum, penicillin $(100 \mathrm{U} / \mathrm{mL})$, and streptomycin $(100$ $\mu \mathrm{g} / \mathrm{mL}$ ). All culture reagents were from Invitrogen or BioConcept.

\section{Synthesis and Radiolabeling of Chelator-Peptide Conjugates}

The peptide-chelator conjugates were synthesized manually according to standard Fmoc chemistry (28) using Rink amide 4-methylbenzhydrylamine resin. The spacer and chelators were consecutively coupled to the peptide using 2-(7-Aza-1H-benzotriazole-1yl)-1,1,3,3-tetramethyluronium hexafluorophosphate as an activating agent. The cleavage of the peptides and simultaneous deprotection of the side chain-protecting groups were performed using trifluoroacetic acid/thioanisole/triisopropylsilane/ $\mathrm{H}_{2} \mathrm{O}(95 / 2 / 2 / 1)$. The crude conjugates were further purified by semipreparative high-performance liquid chromatography (HPLC). The analytic characterization data of the purified conjugates is provided in Supplemental Table 1.

\section{Radiolabeling of Chelator-Peptide Conjugates}

The radioligands were prepared as described in detail in the supplemental data. Briefly, ${ }^{111} \mathrm{In}-\mathrm{DOTA}-\mathrm{AR}$ and ${ }^{64} \mathrm{Cu}-\mathrm{CB}-\mathrm{TE} 2 \mathrm{~A}-$ AR were prepared by dissolving $10 \mu \mathrm{g}$ of the peptides in acetate buffer followed by incubation with ${ }^{111} \mathrm{InCl}_{3}(100-180 \mathrm{MBq})$ or ${ }^{64} \mathrm{CuCl}_{2}(100-120 \mathrm{MBq})$ for $30 \mathrm{~min}$ at $95^{\circ} \mathrm{C}$. Purified ${ }^{68} \mathrm{Ga}(\mathrm{III})$ (250-300 MBq) and ${ }^{67} \mathrm{GaCl}_{3}(100-180 \mathrm{MBq})$ were used for the labeling of NODAGA-AR-02 $(10 \mu \mathrm{g})$ in $\mathrm{NH}_{4}$-acetate buffer $(0.2$ $\mathrm{mol} / \mathrm{L}, \mathrm{pH} 4.0$ ), followed by incubation for $10 \mathrm{~min}$ at room temperature. For ${ }^{99 \mathrm{~m}} \mathrm{Tc}-\mathrm{N} 4-\mathrm{AR}$ preparation, N4-AR $(1 \mathrm{mmol} / \mathrm{L})$ was dissolved in a mixture $(8: 2 \mathrm{v} / \mathrm{v})$ of acetic acid $(50 \mathrm{mmol} / \mathrm{L})$ and ethanol. A reaction mixture of phosphate buffer $(0.5 \mathrm{~mol} / \mathrm{L}, \mathrm{pH}$ 11.5; $50 \mu \mathrm{L})$ and sodium citrate $(0.1 \mathrm{~mol} / \mathrm{L}, 5 \mu \mathrm{L}), \mathrm{Na}^{99 \mathrm{~m}^{9} \mathrm{TcO}_{4}}$ generator eluate $(650-750 \mathrm{MBq}, 700 \mu \mathrm{L}), \mathrm{N} 4-\mathrm{AR}$ solution $(20$ nmol, $20 \mu \mathrm{L}$ ), and freshly prepared $\mathrm{SnCl}_{2}$ solution in ethanol (25 mg, $25 \mu \mathrm{L}$ ) was incubated at room temperature for $30 \mathrm{~min}$. All radiolabeled peptides were analyzed with analytic HPLC. For biodistribution, the radioligands were diluted with $0.9 \% \mathrm{NaCl}$ ( $0.1 \%$ bovine serum albumin).

\section{Binding Affinity Measurements}

The inhibitory concentration of $50 \%\left(\mathrm{IC}_{50}\right)$ values were determined by in vitro GRPr autoradiography on cryostat sections of 
well-characterized prostate carcinomas, as described previously (5). The radioligand used was ${ }^{125} \mathrm{I}_{-} \mathrm{Tyr}^{4}$-bombesin, known to preferentially label GRPrs (29).

\section{Cellular Uptake Kinetics}

PC-3 cells were seeded into 6-well plates overnight $(0.8-$ $1.0 \cdot 10^{6}$ cells per well). On the day of the experiment the medium was removed and the cells were washed twice with fresh medium (Dulbecco modified Eagle medium, $1 \%$ fetal bovine serum, $\mathrm{pH}$ 7.4) and incubated for $1 \mathrm{~h}$ at $37^{\circ} \mathrm{C}$. Approximately $3 \mathrm{kBq}$ of the radioligand $(0.25 \mathrm{pmol})$ were added to the medium, and the cells were incubated (in triplicates) for $0.5,1,2$, and $4 \mathrm{~h}$ at $37^{\circ} \mathrm{C}, 5 \%$ $\mathrm{CO}_{2}$. A 1,000-fold excess of each blocking agent was used to determine nonspecific internalization. At each time point, the cells were treated exactly as described recently (11).

\section{The Fate of GRPr-Bound Radiopeptides In Vitro}

PC-3 cells were seeded into 6-well plates and treated as described in the "Cellular Uptake Kinetics" section. The plates were placed on ice for $30 \mathrm{~min}$; an excess of blocking agent was added to selected wells to determine nonspecific binding. The radioligands $(0.25 \mathrm{pmol}, 3 \mathrm{kBq})$ were added to the medium and allowed to bind to the cells for $2 \mathrm{~h}$ at $4{ }^{\circ} \mathrm{C}$. After the incubation, the cells were washed twice with ice-cold phosphate-buffered saline, and $1 \mathrm{~mL}$ of fresh prewarmed culture medium was added to each well, followed by incubation for 10, 20, and $30 \mathrm{~min}$ and 1, 2, and 4 $\mathrm{h}\left(37^{\circ} \mathrm{C}, 5 \% \mathrm{CO}_{2}\right)$. At each time point, the plates were treated exactly as described recently (11).

\section{Immunofluorescence Microscopy}

Immunofluorescence microscopy-based internalization assays with HEK-GRPr-expressing cells were performed as previously described (17). The cells were treated either with $10 \mathrm{nmol}$ of bombesin per liter or with $1 \mu \mathrm{mol}$ of all conjugates per liter. Or, to evaluate potential antagonism, cells were treated with $10 \mathrm{nmol}$ of bombesin per liter in the presence of a 100-fold excess of all conjugates for $30 \mathrm{~min}$ at $37^{\circ} \mathrm{C}, 5 \% \mathrm{CO}_{2}$, in growth medium and then processed for immunofluorescence microscopy using the mouse monoclonal hemagglutinine-epitope antibody at a dilution of 1:1,000 as a first antibody (Covance) and Alexa Fluor 488 goat antimouse $\operatorname{IgG}(\mathrm{H}+\mathrm{L})$ at a dilution of 1:600 as a secondary antibody (Molecular Probes). The cells were imaged using a Leica DM RB immunofluorescence microscope and an Olympus DP10 camera.

\section{Calcium Mobilization Assay}

Intracellular calcium mobilization was measured in PC-3 cells using the Fluo-4NW Calcium Assay kit (Molecular Probes) as described previously (17). Briefly, PC-3 cells were seeded (10,000 cells per well) in 96 -well plates and cultured for $2 \mathrm{~d}$ at $37^{\circ} \mathrm{C}, 5 \%$ $\mathrm{CO}_{2}$. On the day of the experiment, the cells were washed with assay buffer (1× Hank's balanced salt solution, $N$-(2-hydroxyethyl)piperazine- $N^{\prime}$-(2-ethanesulfonic acid)) containing 2.5 mmol of probenecid per liter. The cells were loaded with Fluo$4 \mathrm{NW}$ dye $(100 \mu \mathrm{L} /$ well $)$ in assay buffer for $30 \mathrm{~min}$ at $37^{\circ} \mathrm{C}$ and $5 \% \mathrm{CO}_{2}$ and for $30 \mathrm{~min}$ at room temperature. The dye-loaded cells were transferred to a SpectraMax M2 ${ }^{\mathrm{e}}$ (Molecular Devices), and intracellular $\mathrm{Ca}^{2+}$ mobilization was recorded in a kinetic experiment for $60 \mathrm{~s}$ at room temperature monitoring fluorescence emission at $520 \mathrm{~nm}\left(\lambda_{\mathrm{ex}}=485 \mathrm{~nm}\right.$, where $\lambda_{\mathrm{ex}}$ is the excitation wavelength) in the presence of the compounds when applied at $1 \mu \mathrm{mol} / \mathrm{L}$. Maximum fluorescence was measured after the addition of $25 \mu \mathrm{mol}$ of ionomycin per liter (17). All experiments were repeated at least 3 times in triplicates.

\section{Biodistribution in PC-3 Tumor-Bearing Nude Mice}

All animal experiments were performed in compliance with the Swiss regulations (permit 789).

Female nude mice were implanted subcutaneously with $10^{6}$ PC3 cells, which were freshly expanded in sterilized phosphate-buffered saline ( $\mathrm{pH}$ 7.4). Eleven days after inoculation, the tumors grew to a size of 4-7 mm. The mice were injected with 10 pmol of the radiotracers $(0.15-0.40 \mathrm{MBq}, 100 \mu \mathrm{L})$ via the tail vein. For the determination of nonspecific uptake in the tumor or receptor-positive organs, a group of 4 animals was preinjected (5 min) with 20 $\mathrm{nmol}$ of unlabeled peptide. Mice were sacrificed at 1, 4, and $24 \mathrm{~h}$, and the organs of interest were collected, rinsed of excess blood, weighed, and counted in a $\gamma$-counter. The biodistribution studies of all radioconjugates were performed accordingly. The percentage injected activity per gram (\%IA/g) was calculated for each tissue. For biodistribution studies of ${ }^{68} \mathrm{Ga}-\mathrm{NODAGA}-\mathrm{AR}$, mice were sacrificed at $1 \mathrm{~h}$ after injection.

\section{SPECT/CT Using ${ }^{111} \mathrm{In}-\mathrm{DOTA-AR}$ and ${ }^{99 m}$ Tc-N4-AR}

PC-3 tumor-bearing nude mice were injected with $5 \mathrm{MBq}$ of

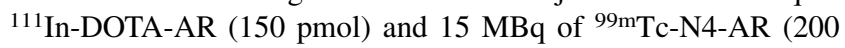
pmol). The mice were anesthetized $12 \mathrm{~h}$ after injection, and images were acquired using a clinical SPECT/CT camera (Symbia T2; Siemens). Iteratively reconstructed SPECT images (4 subsets, 8 iterations) were fused with 3-dimensional reconstructed images from the CT study (two 1.25 -mm slices, $130 \mathrm{kV}, 48 \mathrm{~mA}$ ).

\section{PET/CT Using ${ }^{68}$ Ga-NODAGA-AR and ${ }^{64} \mathrm{Cu}-\mathrm{CB}-\mathrm{TE} 2 \mathrm{~A}-\mathrm{AR}$}

PC-3 tumor-bearing nude mice were sacrificed $1 \mathrm{~h}$ after injection of $2 \mathrm{MBq}$ of ${ }^{68} \mathrm{Ga}-\mathrm{NODAGA}-\mathrm{AR}(150 \mathrm{pmol})$ and $12 \mathrm{~h}$ after injection of $1.5 \mathrm{MBq}$ of ${ }^{64} \mathrm{Cu}-\mathrm{CB}-\mathrm{TE} 2 \mathrm{~A}-\mathrm{AR}$ (150 pmol), and images were acquired using a clinical PET/CT scanner (Discovery STE; GE Healthcare). PET emission events were collected in 3dimensional scanning mode (septa out) over $60 \mathrm{~min}$. The acquired data were corrected for ${ }^{68} \mathrm{Ga}$ decay and random events and reconstructed using the manufacturer's 3-dimensional ordered-subset expectation maximization algorithm. The images were fused with 3-dimensional reconstructed images from the CT study (sixteen 0.625-mm slices, $120 \mathrm{keV}, 320 \mathrm{~mA}$ ).

\section{Statistical Analysis}

Data are expressed as mean $\pm \mathrm{SD}$, calculated on Microsoft Excel. Prism 5 software (GraphPad Software) was used to determine statistical significance at the $95 \%$ confidence level, with a $P$ value of less than 0.05 being considered significantly different.

\section{RESULTS}

\section{Chemistry and Radiochemistry}

The synthesis yields of the peptide-chelator conjugates ranged from $30 \%$ to $35 \%$. All conjugates showed purities greater than $95 \%$, as confirmed by HPLC; identities were confirmed by mass spectroscopy (Supplemental Table 1). ${ }^{68} \mathrm{Ga},{ }^{67} \mathrm{Ga}$, and ${ }^{99 \mathrm{~m}} \mathrm{Tc}$ were labeled at room temperature (30 min), with radiolabeling yields greater than $97 \%$ at specific activities of 50,30 , and $37 \mathrm{GBq}_{\mu \mathrm{mol}}^{-1}$, respectively. ${ }^{111} \mathrm{In}$ - and ${ }^{64} \mathrm{Cu}$-labeled conjugates were obtained by 
incubation at elevated temperature $\left(95^{\circ} \mathrm{C}, 30 \mathrm{~min}\right)$, with labeling yields of $95 \%$ or greater at a maximum specific

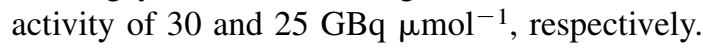

\section{Binding Affinity}

Compared with the reference peptide JMV594 (30) $\left(\mathrm{IC}_{50}, 5.6 \pm 1.8 \mathrm{nmol} / \mathrm{L}\right)$, DOTA-AR and NODAGA-AR still retained reasonable affinity to the $\mathrm{GRPr}\left(\mathrm{IC}_{50}, 18 \pm 7\right.$ and $25 \pm 6 \mathrm{nmol} / \mathrm{L}$, respectively). The $\mathrm{IC}_{50}$ value of $\mathrm{CB}-$ TE2A-AR $\left(\mathrm{IC}_{50}, 5.5 \pm 1.3 \mathrm{nmol} / \mathrm{L}\right)$ was comparable to JMV594, whereas N4-AR showed the highest binding affinity $\left(\mathrm{IC}_{50}, 2.5 \pm 0.6 \mathrm{nmol} / \mathrm{L}\right)$.

\section{Cellular Uptake Kinetics}

All conjugates showed specific and time-dependent cellular uptake at $37^{\circ} \mathrm{C}$ (Fig. 2). Blocking studies demonstrated that the uptake was receptor-mediated. ${ }^{111}$ In-DOTA-AR and ${ }^{67} \mathrm{Ga}-\mathrm{NODAGA}-\mathrm{AR}$ showed rapid binding to the membrane receptors. Within $2 \mathrm{~h}$ of incubation, the specifically bound fraction leveled off at $20 \%$. The specifically bound radiopeptide was $24.3 \% \pm 1.4 \%$ for ${ }^{64} \mathrm{Cu}-\mathrm{CB}-\mathrm{TE} 2 \mathrm{~A}-\mathrm{AR}$ and $31.4 \% \pm 0.7 \%$ for ${ }^{99 m} \mathrm{Tc}-\mathrm{N} 4-\mathrm{AR}$. For all conjugates, the internalized fraction was less than $10 \%$ at $4 \mathrm{~h}$.

\section{The Fate of GRPr-Bound Radiopeptides In Vitro}

The fate of the receptor-bound radiopeptides was studied by a temperature shift experiment; the 4 radiotracers showed similar behavior in that they presented a stable receptor-ligand interaction (Supplemental Fig. 1). ${ }^{67} \mathrm{Ga}-$ NODAGA-AR showed the highest dissociated fraction ( $\sim 50 \%$ ), whereas the ${ }^{64} \mathrm{Cu}$ and ${ }^{99 \mathrm{~m}} \mathrm{Tc}$ conjugates bound more strongly, with almost $60 \%$ of the peptide still bound to the receptor after $4 \mathrm{~h}$ at $37^{\circ} \mathrm{C}$. The internalized fraction after $4 \mathrm{~h}$ at $37^{\circ} \mathrm{C}$ was less than $20 \%$ for all radiotracers.

\section{Immunofluorescence Microscopy}

The antagonistic properties of the conjugates were assessed by immunofluorescence-based internalization assay using HEK-GRPr-expressing cells. Figure 3A shows that $10 \mathrm{nmol}$ of bombesin per liter were able to trigger receptor internalization. None of the 4 conjugates was able to stimulate GRPr internalization, even at a concentration of 1,000 $\mathrm{nmol} / \mathrm{L}$. However, at a concentration of $1,000 \mathrm{nmol} / \mathrm{L}$ together with $10 \mathrm{nmol}$ of bombesin per liter, the peptides were able to prevent the bombesin-induced receptor internalization.

\section{Calcium Mobilization Assay}

The $\mathrm{Ca}^{2+}$ mobilization assay allows determining quantitatively bombesin antagonist potency. Dose-response curves of the 4 conjugates in PC-3 cells are shown in Figure 3B. All 4 peptides behaved as antagonists, shifting the dose-response curve of $\mathrm{Tyr}^{4}$-bombesin $(10 \mu \mathrm{mol} / \mathrm{L})$ to a higher molar range. The CB-TE2A-AR and N4-AR showed a pronounced shift to the right, confirming the superior antagonist potency of these 2 peptides. Moreover, tested alone at 1 and $10 \mu \mathrm{mol} / \mathrm{L}$, the peptides did not cause an intracellular $\mathrm{Ca}^{2+}$ flux (Fig. 3B).

\section{Biodistribution}

The comparative pharmacokinetics of the 4 radiopeptides are summarized in Table 1, and relevant tumor-tonormal-tissue ratios are summarized in Table 2. All 4 radiopeptides showed fast blood clearance (only $0.02 \pm$ $0.001-0.27 \pm 0.07 \% \mathrm{IA} / \mathrm{g}$ left in blood at $4 \mathrm{~h}$ after injection). The tumor uptake was specific, as shown with blocking experiments, and ranged between $7.1 \pm 3.3$ and 31.0 $\pm 3.3 \% \mathrm{IA} / \mathrm{g}$ at $1 \mathrm{~h}$ after injection for 4 radiopeptides. The
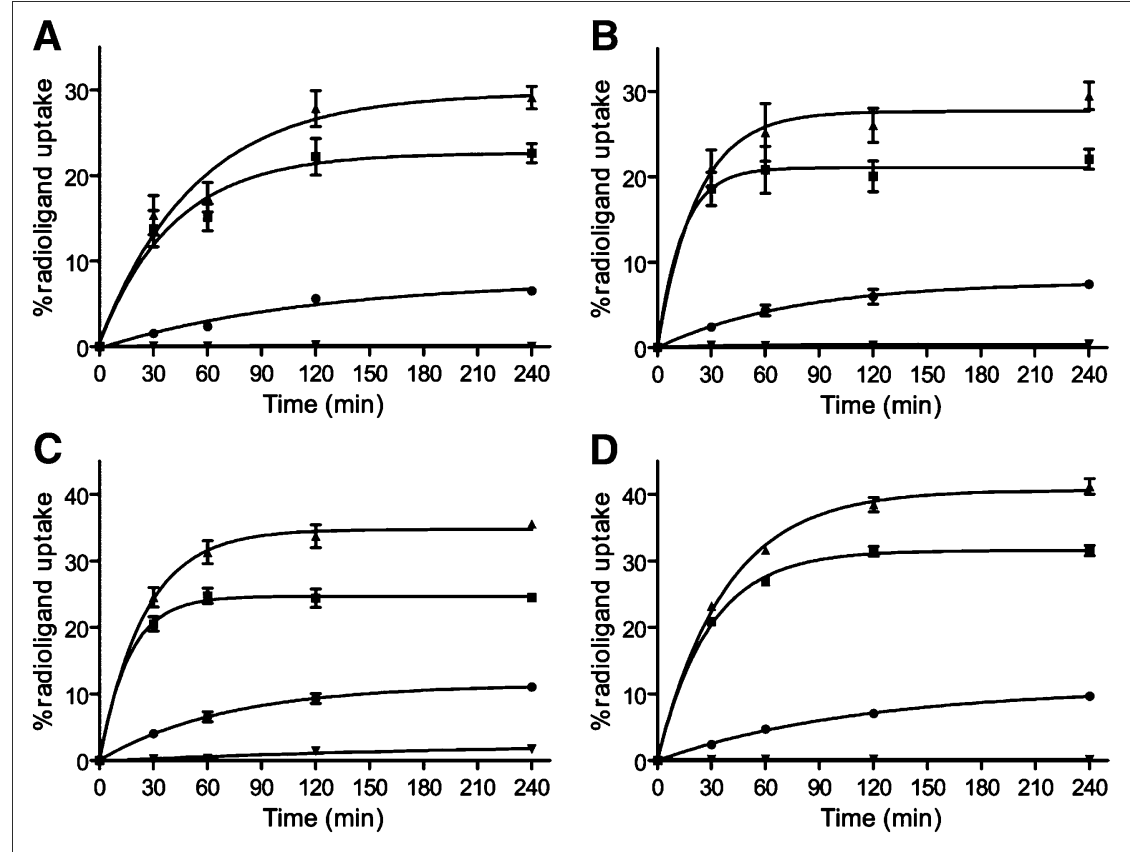

FIGURE 2. Cellular uptake profile of ${ }^{111} \mathrm{In}$ DOTA-AR (A), ${ }^{67}$ Ga-NODAGA-AR (B), ${ }^{64} \mathrm{Cu}-$ CB-TE2A-AR (C), and 99mTc-N4-AR (D) as measured with PC-3 cells. Percentage of specific bound $(\square)$, specific internalized $(\boldsymbol{\bullet})$, and total specific cell uptake $(\boldsymbol{\Delta})$ was determined with respect to total added activity. Nonspecific uptake $(\boldsymbol{\nabla})$ was determined by pretreating cells with 1,000-fold excess of blocking agent (BIM26226) before adding radioligand. Values and SD are result of 2 independent experiments, with triplicates in each experiment. 


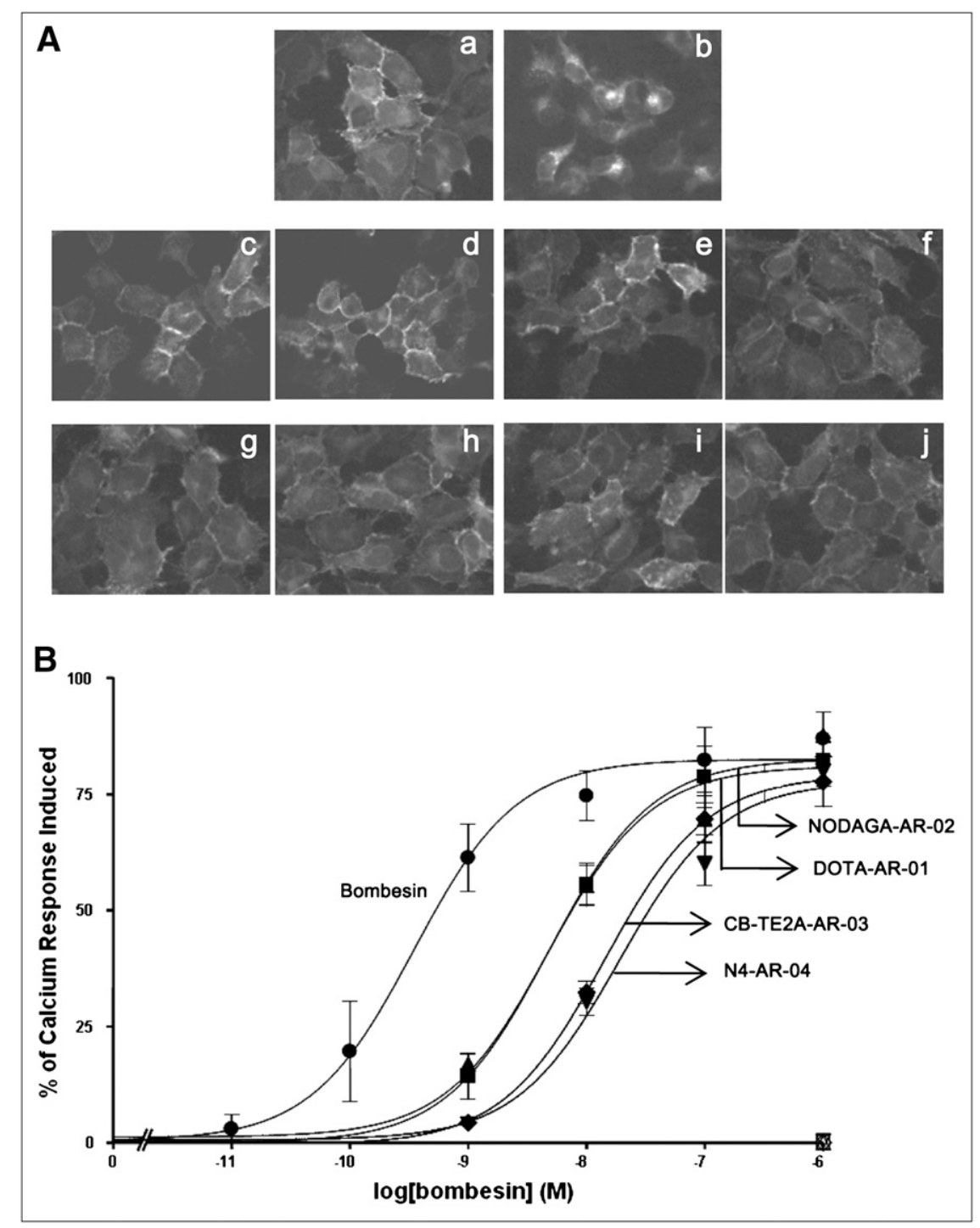

FIGURE 3. (A) Immunofluorescence microscopy-based internalization assay with HEK-GRPr cells, DOTA-AR (c, d), NODAGA-AR (e, f), CB-TE2A-AR (g, h), and N4-AR (i, j). Control experiment shows membrane-bound GRPr in absence of peptide (a); bombesin agonist $(10 \mathrm{nmol} / \mathrm{L})$ triggers massive GRPr internalization (b). Antagonist conjugates failed to induce GRPr internalization, even at concentration of 1 $\mu \mathrm{mol} / \mathrm{L}$ (c, e, g, and i); antagonist conjugates at a concentration of $1 \mu \mathrm{mol} / \mathrm{L}$ efficiently blocked bombesin agonist-mediated GRPr internalization (d, f, h, and j). (B) Doseresponse curves of bombesin analogs determined by calcium release assay as described in "Materials and Methods" section. All conjugates behave like antagonists, shifting dose-response curve of bombesin to higher molar range when applied at 1 $\mu \mathrm{mol} / \mathrm{L}$. Data are expressed as percentage of maximum calcium response induced by ionomycin.

and ${ }^{67 / 68} \mathrm{Ga}$ peptides had a low kidney uptake already at the 1-h time point (Table 1; Supplemental Fig. 2).

\section{Imaging Studies}

SPECT/CT images acquired at $12 \mathrm{~h}$ after injection clearly showed high tumor uptake and fast washout from other organs for both ${ }^{111} \mathrm{In}-\mathrm{DOTA}-\mathrm{AR}$ and ${ }^{99 \mathrm{~m} T \mathrm{Tc}-\mathrm{N} 4-\mathrm{AR}}$ (Fig. 4A). PET/CT images were acquired at $1 \mathrm{~h}$ after injection for ${ }^{68} \mathrm{Ga}-\mathrm{NODAGA}-\mathrm{AR}$ and at $12 \mathrm{~h}$ for ${ }^{64} \mathrm{Cu}-\mathrm{CB}-$ TE2A-AR (Fig. 4B). ${ }^{68} \mathrm{Ga}-\mathrm{NODAGA}-\mathrm{AR}$ exhibited high uptake in the abdomen, mainly because of pancreas uptake, and the image of ${ }^{64} \mathrm{Cu}-\mathrm{CB}-\mathrm{TE} 2 \mathrm{~A}-\mathrm{AR}$ at the late time point $(12 \mathrm{~h})$ resulted in an excellent tumor-to-background ratio due to washout of the radioligand from all organs except the tumor.

\section{DISCUSSION}

Because of the overexpression of GRPr on a variety of major human tumors, development of radiolabeled bomb- 
TABLE 1

Biodistribution of ${ }^{111} \mathrm{In}-\mathrm{DOTA}-\mathrm{AR},{ }^{68} \mathrm{Ga}-\mathrm{NODAGA}-\mathrm{AR},{ }^{64} \mathrm{Cu}-\mathrm{CB}-\mathrm{TE} 2 \mathrm{~A}-\mathrm{AR}$, and ${ }^{99 \mathrm{~m} T \mathrm{~T}-\mathrm{N} 4-\mathrm{AR}}$ in Human PC-3 Tumor-Bearing Nude Mice

\begin{tabular}{|c|c|c|c|c|c|}
\hline Organ & Time after injection $(h)^{\star}$ & ${ }^{111}$ In-DOTA-AR & ${ }^{68} \mathrm{Ga}-\mathrm{NODAGA}-\mathrm{AR}^{\dagger}$ & ${ }^{64} \mathrm{Cu}-\mathrm{CB}-\mathrm{TE} 2 \mathrm{~A}-\mathrm{AR}$ & 99mTc-N4-AR \\
\hline \multirow[t]{3}{*}{ Blood } & 1 & $0.21 \pm 0.02$ & $0.42 \pm 0.30$ & $1.10 \pm 0.11$ & $1.20 \pm 0.18$ \\
\hline & 4 & $0.02 \pm 0.001$ & & $0.18 \pm 0.03$ & $0.27 \pm 0.07$ \\
\hline & 24 & $0.005 \pm 0.001$ & & $0.03 \pm 0.02$ & $0.04 \pm 0.01$ \\
\hline \multirow[t]{3}{*}{ Tumor } & 1 & $10.56 \pm 0.70$ & $7.11 \pm 3.26$ & $31.02 \pm 3.35$ & $24.98 \pm 5.22$ \\
\hline & 4 & $8.63 \pm 1.13$ & & $24.02 \pm 2.43$ & $32.85 \pm 4.25$ \\
\hline & 24 & $3.23 \pm 0.52$ & & $6.14 \pm 0.34$ & $16.55 \pm 3.76$ \\
\hline \multirow[t]{3}{*}{ Kidneys } & 1 & $1.85 \pm 0.15$ & $1.13 \pm 0.21$ & $6.53 \pm 0.52$ & $5.92 \pm 0.55$ \\
\hline & 4 & $1.38 \pm 0.37$ & & $1.85 \pm 0.32$ & $2.74 \pm 0.40$ \\
\hline & 24 & $0.24 \pm 0.01$ & & $0.41 \pm 0.07$ & $0.85 \pm 0.26$ \\
\hline \multirow[t]{3}{*}{ Pancreas } & 1 & $10.96 \pm 0.57$ & $8.19 \pm 2.06$ & $63.31 \pm 2.69$ & $66.01 \pm 4.86$ \\
\hline & 4 & $0.52 \pm 0.05$ & & $6.01 \pm 0.79$ & $11.38 \pm 1.44$ \\
\hline & 24 & $0.01 \pm 0.01$ & & $0.12 \pm 0.16$ & $0.20 \pm 0.08$ \\
\hline \multirow[t]{3}{*}{ Muscle } & 1 & $0.08 \pm 0.02$ & $0.16 \pm 0.12$ & $0.34 \pm 0.05$ & $0.24 \pm 0.05$ \\
\hline & 4 & $0.02 \pm 0.01$ & & $0.19 \pm 0.17$ & $0.07 \pm 0.02$ \\
\hline & 24 & $0.01 \pm 0.003$ & & $0.05 \pm 0.05$ & $0.08 \pm 0.07$ \\
\hline \multirow[t]{3}{*}{ Intestine } & 1 & $1.16 \pm 0.24$ & $1.30 \pm 0.61$ & $9.47 \pm 1.16$ & $6.58 \pm 1.04$ \\
\hline & 4 & $0.10 \pm 0.04$ & & $1.76 \pm 0.33$ & $1.35 \pm 0.37$ \\
\hline & 24 & $0.02 \pm 0.005$ & & $0.14 \pm 0.03$ & $0.10 \pm 0.06$ \\
\hline \multirow[t]{3}{*}{ Liver } & 1 & $0.22 \pm 0.01$ & $0.19 \pm 0.05$ & $4.37 \pm 0.30$ & $4.91 \pm 0.95$ \\
\hline & 4 & $0.09 \pm 0.01$ & & $2.63 \pm 0.64$ & $3.36 \pm 0.74$ \\
\hline & 24 & $0.03 \pm 0.01$ & & $0.81 \pm 0.06$ & $1.29 \pm 0.42$ \\
\hline \multirow[t]{3}{*}{ Stomach } & 1 & $2.01 \pm 0.36$ & $1.26 \pm 0.42$ & $9.74 \pm 0.45$ & $7.15 \pm 0.99$ \\
\hline & 4 & $0.56 \pm 0.18$ & & $4.26 \pm 1.51$ & $5.26 \pm 0.89$ \\
\hline & 24 & $0.01 \pm 0.002$ & & $0.14 \pm 0.16$ & $0.35 \pm 0.24$ \\
\hline \multirow[t]{3}{*}{ Bone } & 1 & $0.16 \pm 0.06$ & $0.09 \pm 0.03$ & $0.85 \pm 0.22$ & $0.82 \pm 0.11$ \\
\hline & 4 & $0.12 \pm 0.04$ & & $0.26 \pm 0.18$ & $0.41 \pm 0.13$ \\
\hline & 24 & $0.04 \pm 0.02$ & & $0.02 \pm 0.001$ & $0.18 \pm 0.09$ \\
\hline
\end{tabular}

*Biodistribution data of blocking studies performed at $4 \mathrm{~h}$ after injection are provided in Supplemental Table 2.

${ }^{\dagger}$ Biodistribution was performed only at $1 \mathrm{~h}$ after injection because of the short half-life of ${ }^{68} \mathrm{Ga}$.

Data are expressed as \% IA/g of tissue and are presented as mean \pm SD $(n=4-6)$.

esin peptides paves an excellent way for targeted imaging and radionuclide therapy of GRPr-positive tumors. Over the past 2 decades, several groups, including our laboratory, reported several radiolabeled agonist-based bombesin peptides $(9,11,26,31,32)$. Although these agonists were believed to be ideal targeting ligands because of the inter-
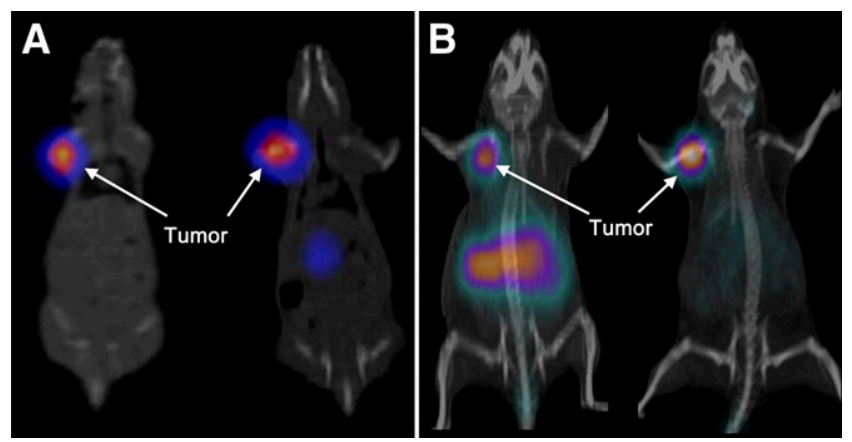

FIGURE 4. (A) SPECT/CT images of PC-3 tumor-bearing nude mice at $12 \mathrm{~h}$ after injection of ${ }^{99 \mathrm{mT}} \mathrm{T}-\mathrm{N} 4-\mathrm{AR}$ (left) and ${ }^{111} \mathrm{In}-\mathrm{DOTA}-$ AR (right). (B) PET/CT images of PC-3 tumor-bearing nude mice at 1 $\mathrm{h}$ after injection of ${ }^{68} \mathrm{Ga}-\mathrm{NODAGA}-\mathrm{AR}$ (left) and $12 \mathrm{~h}$ after injection of ${ }^{64} \mathrm{Cu}-\mathrm{CB}-\mathrm{TE} 2 \mathrm{~A}-\mathrm{AR}$ (right). nalization of the receptor-agonist complexes, their high and sustained uptake in the normal receptor-positive organs resulted in unfavorable pharmacokinetics. Recently, radiolabeled bombesin-based antagonists showed improved pharmacokinetics in animal models bearing PC-3 or LnCap tumors (17-20,33). In the bombesin family field, use of antagonists may have an additional benefit because agonists were shown to be mitogenic. The ideal targeting properties of bombesin antagonists such as high tumor uptake, fast washout from the normal organs, and improved stability have attracted our interest during the last few years and boosted our efforts toward clinical translation of these molecules for targeted imaging and radionuclide therapy. Among the several bombesin antagonists studied in our laboratory, the statine-based analogs showed good pharmacokinetics.

With this background, we designed the current study to develop clinically translatable bombesin antagonists by conjugating $\mathrm{AR}$ to different chelators. Conjugation of different chelators allows labeling of AR with a variety of radionuclides and subsequent application in different imaging modalities (SPECT/CT and PET/CT) but also in targeted radionuclide therapy after intelligent replacement 
TABLE 2

Tumor-to-Tissue Ratios

\begin{tabular}{|c|c|c|c|c|}
\hline Tumor to... & ${ }^{111}$ In-DOTA-AR & ${ }^{68} \mathrm{Ga}-\mathrm{NODAGA}-\mathrm{AR}^{\star}$ & ${ }^{64} \mathrm{Cu}-\mathrm{CB}-\mathrm{TE} 2 \mathrm{~A}-\mathrm{AR}$ & 99mTc-N4-AR \\
\hline \multicolumn{5}{|l|}{ Blood } \\
\hline $1 \mathrm{~h}$ after injection & 50.3 & 16.9 & 28.2 & 20.8 \\
\hline $4 \mathrm{~h}$ after injection & 431 & & 133 & 121 \\
\hline $24 \mathrm{~h}$ after injection & 646 & & 205 & 413 \\
\hline \multicolumn{5}{|l|}{ Kidneys } \\
\hline $1 \mathrm{~h}$ after injection & 5.7 & 6.3 & 4.7 & 4.2 \\
\hline $4 \mathrm{~h}$ after injection & 6.2 & & 13.0 & 12.0 \\
\hline $24 \mathrm{~h}$ after injection & 13.4 & & 15.0 & 19.5 \\
\hline \multicolumn{5}{|l|}{ Muscle } \\
\hline $1 \mathrm{~h}$ after injection & 132 & 37.4 & 91.2 & 104 \\
\hline $4 \mathrm{~h}$ after injection & 431 & & 126 & 469 \\
\hline $24 \mathrm{~h}$ after injection & 323 & & 123 & 207 \\
\hline \multicolumn{5}{|l|}{ Liver } \\
\hline $1 \mathrm{~h}$ after injection & 48 & 44.4 & 7.1 & 5.1 \\
\hline $4 \mathrm{~h}$ after injection & 95.9 & & 9.1 & 9.8 \\
\hline $24 \mathrm{~h}$ after injection & 107 & & 7.6 & 12.8 \\
\hline \multicolumn{5}{|l|}{ Intestine } \\
\hline $1 \mathrm{~h}$ after injection & 9.1 & 16.9 & 3.3 & 3.8 \\
\hline $4 \mathrm{~h}$ after injection & 86.3 & & 13.6 & 24.3 \\
\hline $24 \mathrm{~h}$ after injection & 161 & & 43.8 & 165 \\
\hline
\end{tabular}

of the imaging radionuclides with surrogate therapeutic radionuclides, arriving at theranostic pairs. We used different chelators and conjugation strategies for this purpose: DOTA, as a monoamide, coupled for ${ }^{111}$ In labeling for SPECT $\left({ }^{111} \mathrm{In}^{3+}\right.$ was shown to be a close surrogate of the $\beta$-emitters ${ }^{177} \mathrm{Lu}^{3+}$ and $\left.{ }^{90} \mathrm{Y}^{3+}(11)\right)$; NODAGA for ${ }^{67 / 68} \mathrm{Ga}$ labeling; CB-TE2A for ${ }^{64} \mathrm{Cu}$ and its $\beta$-emitting surrogate ${ }^{67} \mathrm{Cu}$; and finally $\mathrm{N} 4$ for the labeling with ${ }^{99 \mathrm{~m}} \mathrm{Tc}$ and possibly with its matched-pair ${ }^{186 / 188} \operatorname{Re} \beta$-emitters (17).

An important conclusion of our study is that even after $\mathrm{N}$-terminal modifications (coupling of $\mathrm{PEG}_{4}$ as pharmacokinetic modulator plus chelator), all 4 peptide conjugates retained significant binding affinity to the GRPr. However, side-by-side comparison showed that conjugation of different chelators to the same bombesin antagonist peptide, AR, significantly influenced the receptor affinity. This may be due in part to the charge on the $N$ terminus; positive charges appear to improve affinity if used along with agonists (34). At this time, there is no explanation for this improvement.

In addition, the 4 peptides were shown to hold the antagonistic potency of the parent peptide. Bombesintriggered $\mathrm{Ca}^{2+}$ mobilization was successfully antagonized by all peptides; the half maximal effective antagonist concentration values correlated well with the $\mathrm{IC}_{50}$ values.

The in vitro assay showed that all 4 radioligands have a similar cellular uptake profile, for which a high amount of radioligand specifically binds to the receptors and induces internalization of receptor to a lesser extent (Fig. 2). The binding-dissociation experiments showed that on binding to the receptor (at $4^{\circ} \mathrm{C}$ for $2 \mathrm{~h}$ ), increase in temperature $\left(37^{\circ} \mathrm{C}\right)$ and exposure to fresh medium resulted in 2 such phenomena as dissociation and internalization of the radioligand (Fig. 2). The antagonist ${ }^{99 \mathrm{~m}} \mathrm{Tc}-\mathrm{N} 4-\mathrm{AR}$ binds strongly to the receptors, showing less dissociation than with the other radioligands, whereas, compared with other radioligands, the amount of ${ }^{67}$ Ga-NODAGA-AR dissociated is greater than $40 \%$.

The pharmacokinetic data show similarities but also remarkable differences among the 4 radiopeptides. All show fast blood clearance and specific uptake in tumor and physiologically GRPr-expressing organs such as the pancreas, intestine, and adrenals. The uptake in the tumor and other GRPr-positive organs correlated not only with $\mathrm{IC}_{50}$ values but also with antagonist potency. The retention in the tumor seems to correlate with the rate of dissociation from the receptor in cultured cells.

The 4 radiopeptides may be grouped according to their tumor uptake; ${ }^{64} \mathrm{Cu}-\mathrm{CB}-\mathrm{TE} 2 \mathrm{~A}-\mathrm{AR}$ and ${ }^{99 \mathrm{~m}} \mathrm{Tc}-\mathrm{N} 4-\mathrm{AR}$ are outstanding in this regard. They show high tumor uptake at early time points, which stays or even increases over $4 \mathrm{~h}$

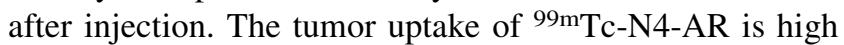
even at $24 \mathrm{~h}$. Compared with previously reported N4-conjugated bombesin antagonists, substitution of $\mathrm{PEG}_{4}$ for the gly-4-amino benzoyl spacer leads to significantly improved tumor-to-normal-tissue ratios (33). Also compared with the potent bombesin antagonist ${ }^{99 \mathrm{~m}} \mathrm{Tc}$-demobesin 1 , ${ }^{99 m} \mathrm{Tc}-\mathrm{N} 4-\mathrm{AR}$ shows higher tumor-to-normal-organ ratios at all time points in the PC-3 tumor model (17). If the ${ }^{186 / 188} \mathrm{Re}$ congener complex shows the same or similar pharmacokinetics, this therapeutic radiopeptide may be of relevance for targeted radionuclide therapy of GRPrpositive tumors. 
${ }^{64} \mathrm{Cu}-\mathrm{CB}-\mathrm{TE} 2 \mathrm{~A}-\mathrm{AR}$ shows high uptake similar to that of ${ }^{99 m}$ Tc-N4-AR at 1 and $4 \mathrm{~h}$, but faster washout was seen at $24 \mathrm{~h}$. Among different chelating systems used for ${ }^{64} \mathrm{Cu}$ labeling, the CB-TE2A chelator showed high in vivo stability of ${ }^{64} \mathrm{Cu}^{2+}$ complexes, resulting in improved pharmacokinetics of the radioconjugates (35). Low liver uptake is considered an indication of high in vivo stability, which was also shown using the ${ }^{64} \mathrm{Cu}-\mathrm{NOTA}-8-\mathrm{Aoc}-\mathrm{BBN}(7-14)$ derivative (26). On the other hand, high uptake and retention in liver tissue is found when DOTA is chosen as chelator; Garrison et al. (35) showed that the bombesin agonist ${ }^{64} \mathrm{Cu}-\mathrm{CB}-\mathrm{TE} 2 \mathrm{~A}-8-\mathrm{Aoc}-\mathrm{BN}(7-14)$ possesses high in vivo stability with significantly lower liver uptake than ${ }^{64} \mathrm{Cu}-$ DOTA-8-Aoc-BN(7-14). The current study demonstrates that ${ }^{64} \mathrm{Cu}-\mathrm{CB}-\mathrm{TE} 2 \mathrm{~A}-\mathrm{AR}$, compared with ${ }^{64} \mathrm{Cu}-\mathrm{CB}-\mathrm{TE} 2 \mathrm{~A}-$ 8-Aoc-BN(7-14), not only showed high in vivo stability but also high tumor uptake. Hence, the combination of bombesin antagonist with CB-TE2A ligand for the development of ${ }^{64} \mathrm{Cu}$-based PET probes combines advantages such as high tumor uptake, favorable pharmacokinetics, and improved in vivo stability of the radiometal complex. ${ }^{64} \mathrm{Cu}-$ CB-TE2A-AR is the first ${ }^{64} \mathrm{Cu}$-labeled bombesin antagonist showing highly promising preclinical data. In addition, on the basis of these properties, one may conclude that ${ }^{67} \mathrm{Cu}-\mathrm{CB}-\mathrm{TE} 2 \mathrm{~A}-\mathrm{AR}$ is a promising therapeutic radiopharmaceutical.

Both ${ }^{111}$ In-DOTA-AR and ${ }^{68} \mathrm{Ga}-N O D A G A-A R$ showed lower uptake in the tumor and receptor-positive organs than

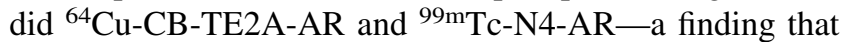
is in accordance with the in vitro binding affinity results, in which CB-TE2A-AR and N4-AR, compared with DOTAAR and NODAGA-AR, showed high affinity to GRPr. Although, showing relatively low tumor uptake, ${ }^{68} \mathrm{Ga}-$ NODAGA-AR may still be interesting for clinical application as a PET agent because this conjugate is labeled with ${ }^{68} \mathrm{Ga}$ at room temperature with high specific activity.

Conjugation of potent peptides to DOTA allows stable complexation with a variety of +3 metal ions, facilitating application of the resulting radioligand for both imaging and targeted radionuclide therapy. Compared with reported DOTA-conjugated bombesin antagonists, ${ }^{111}$ In-DOTA-AR shows improved tumor-to-normal-tissue ratios at all time points (18-20). Therefore, in addition to SPECT, DOTAAR can be a useful targeted therapeutic agent, with immediate clinical translational properties because it can be easily labeled with ${ }^{177} \mathrm{Lu}$ and ${ }^{90} \mathrm{Y}$.

The SPECT/CT and PET/CT images show a clear delineation of the PC-3 tumors. Image acquisition at $12 \mathrm{~h}$ after injection showed good clearance of the radioactivity from the abdominal organs and significant accumulation only in the tumor. The PET/CT image, acquired at $1 \mathrm{~h}$ after injection using ${ }^{68} \mathrm{Ga}-N O D A G A-A R$, showed high abdominal activity, compared with the image acquired using ${ }^{64} \mathrm{Cu}$ CB-TE2A-AR at $12 \mathrm{~h}$ after injection. This finding shows in a remarkable way that the half-life of the radionuclide may be of high relevance in regard to a good image contrast.
Important parameters for good image contrast are the tumor-to-normal-tissue ratios, in particular the tumor-toblood and tumor-to-muscle ratios. For all 4 radiopeptides, these ratios are already high at $1 \mathrm{~h}$ and increase over time. As the kidney uptake of radiopeptides is dose-limiting in radiotherapeutic applications, particular attention is given to the tumor-to-kidney ratio. The high values found here are outstanding and unchallenged by any other radiopeptide.

\section{CONCLUSION}

We have developed 4 different peptide-based radiovectors for the imaging of GRPr-positive tumors. All 4 radiovectors show promising in vitro and in vivo pharmacokinetic performances that may improve diagnostic imaging of cancers overexpressing these receptors. In particular, the encouraging performance of the ${ }^{64} \mathrm{Cu}-\mathrm{CB}-\mathrm{TE} 2 \mathrm{~A}-\mathrm{AR}$ motivated us to introduce this targeting vector into the clinic for use in patients with primary prostate cancer.

\section{DISCLOSURE STATEMENT}

The costs of publication of this article were defrayed in part by the payment of page charges. Therefore, and solely to indicate this fact, this article is hereby marked "advertisement" in accordance with 18 USC section 1734.

\section{ACKNOWLEDGMENTS}

We thank Novartis Pharma for analytic assistance and Sibylle Tschumi, Edith Rauber, and Valentina RufenerSchirp for their expert technical help. This study was funded in part by Bayer Schering Pharma, the Swiss National Science Foundation, and the COST actions D38 and BM0607. No other potential conflict of interest relevant to this article was reported.

\section{REFERENCES}

1. Schottelius M, Wester HJ. Molecular imaging targeting peptide receptors. Methods. 2009; 48:161-177.

2. Reubi JC. Peptide receptors as molecular targets for cancer diagnosis and therapy. Endocr Rev. 2003;24:389-427.

3. Lee S, Xie J, Chen X. Peptides and peptide hormones for molecular imaging and disease diagnosis. Chem Rev. 2010.110:3087-3111.

4. Wild D, Frischknecht M, Zhang H, et al. Alpha- versus beta-particle radiopeptide therapy in a human prostate cancer model $\left({ }^{213} \mathrm{Bi}\right.$-DOTA-PESIN and ${ }^{213} \mathrm{Bi}-$ AMBA versus ${ }^{177}$ Lu-DOTA-PESIN). Cancer Res. 2011;71:1009-1018.

5. Markwalder R, Reubi JC. Gastrin-releasing peptide receptors in the human prostate: relation to neoplastic transformation. Cancer Res. 1999;59:11521159 .

6. Gugger M, Reubi JC. Gastrin-releasing peptide receptors in non-neoplastic and neoplastic human breast. Am J Pathol. 1999;155:2067-2076.

7. Reubi JC, Korner M, Waser B, Mazzucchelli L, Guillou L. High expression of peptide receptors as a novel target in gastrointestinal stromal tumours. Eur J Nucl Med Mol Imaging. 2004;31:803-810.

8. Fleischmann A, Waser B, Reubi JC. Overexpression of gastrin-releasing peptide receptors in tumor-associated blood vessels of human ovarian neoplasms. Cell Oncol. 2007;29:421-433.

9. Nock BA, Nikolopoulou A, Galanis A, et al. Potent bombesin-like peptides for GRP-receptor targeting of tumors with ${ }^{99 \mathrm{~m}} \mathrm{Tc}$ : a preclinical study. J Med Chem. 2005;48:100-110. 
10. Chen X, Park R, Hou Y, et al. microPET and autoradiographic imaging of GRP receptor expression with ${ }^{64} \mathrm{Cu}$-DOTA-[Lys ${ }^{3}$ ]bombesin in human prostate adenocarcinoma xenografts. J Nucl Med. 2004;45:1390-1397.

11. Zhang H, Chen J, Waldherr C, et al. Synthesis and evaluation of bombesin derivatives on the basis of pan-bombesin peptides labeled with indium-111, lutetium-177, and yttrium-90 for targeting bombesin receptor-expressing tumors. Cancer Res. 2004;64:6707-6715.

12. Van de Wiele C, Phonteyne P, Pauwels P, et al. Gastrin-releasing peptide receptor imaging in human breast carcinoma versus immunohistochemistry. J Nucl Med. 2008;49:260-264.

13. Van de Wiele C, Dumont F, Vanden Broecke R, et al. Technetium-99m RP527, a GRP analogue for visualisation of GRP receptor-expressing malignancies: a feasibility study. Eur J Nucl Med. 2000;27:1694-1699.

14. Lantry LE, Cappelletti E, Maddalena ME, et al. ${ }^{177} \mathrm{Lu}-\mathrm{AMBA}$ : synthesis and characterization of a selective ${ }^{177} \mathrm{Lu}$-labeled GRP-R agonist for systemic radiotherapy of prostate cancer. J Nucl Med. 2006;47:1144-1152.

15. Linder KE, Metcalfe E, Arunachalam T, et al. In vitro and in vivo metabolism of Lu-AMBA, a GRP-receptor binding compound, and the synthesis and characterization of its metabolites. Bioconjug Chem. 2009;20:1171-1178.

16. Bodei LFM, Nunn AD, et al. ${ }^{177} \mathrm{Lu}$-AMBA bombesin analogue in hormone refractory prostate cancer patients: a phase I escalation study with single-cycle administrations [abstract]. Eur J Nucl Med Mol Imaging 2007;34(suppl 2):S221.

17. Cescato R, Maina T, Nock B, et al. Bombesin receptor antagonists may be preferable to agonists for tumor targeting. J Nucl Med. 2008;49:318-326.

18. Abd-Elgaliel WR, Gallazzi F, Garrison JC, et al. Design, synthesis, and biological evaluation of an antagonist-bombesin analogue as targeting vector. Bioconjug Chem. 2008;19:2040-2048.

19. Mansi R, Wang X, Forrer F, et al. Evaluation of a 1,4,7,10-tetraazacyclododecane1,4,7,10-tetraacetic acid-conjugated bombesin-based radioantagonist for the labeling with single-photon emission computed tomography, positron emission tomography, and therapeutic radionuclides. Clin Cancer Res. 2009;15:5240-5249.

20. Mansi R, Wang X, Forrer F, et al. Development of a potent DOTA-conjugated bombesin antagonist for targeting GRPr-positive tumours. Eur J Nucl Med Mol Imaging. 2011;38:97-107.

21. Casanueva FF, Perez FR, Casabiell X, Camina JP, Cai RZ, Schally AV. Correlation between the effects of bombesin antagonists on cell proliferation and intracellular calcium concentration in Swiss 3T3 and HT-29 cell lines. Proc Natl Acad Sci USA. 1996;93:1406-1411.

22. Ginj M, Zhang H, Waser B, et al. Radiolabeled somatostatin receptor antagonists are preferable to agonists for in vivo peptide receptor targeting of tumors. Proc Natl Acad Sci USA. 2006;103:16436-16441.
23. Wu AM, Yazaki PJ, Tsai S, et al. High-resolution microPET imaging of carcinoembryonic antigen-positive xenografts by using a copper-64-labeled engineered antibody fragment. Proc Natl Acad Sci USA. 2000;97:8495-8500.

24. Rossin R, Pan D, Qi K, et al. ${ }^{64} \mathrm{Cu}$-labeled folate-conjugated shell cross-linked nanoparticles for tumor imaging and radiotherapy: synthesis, radiolabeling, and biologic evaluation. J Nucl Med. 2005;46:1210-1218.

25. Voss SD, Smith SV, DiBartolo N, et al. Positron emission tomography (PET) imaging of neuroblastoma and melanoma with ${ }^{64} \mathrm{Cu}-\mathrm{SarAr}$ immunoconjugates. Proc Natl Acad Sci USA. 2007;104:17489-17493.

26. Prasanphanich AF, Nanda PK, Rold TL, et al. $\left[{ }^{64} \mathrm{Cu}-\mathrm{NOTA}-8-\mathrm{Aoc}-\mathrm{BBN}(7-14)\right.$ $\mathrm{NH}_{2}$ ] targeting vector for positron-emission tomography imaging of gastrin-releasing peptide receptor-expressing tissues. Proc Natl Acad Sci USA. 2007;104:1246212467.

27. Maecke HR, Hofmann M, Haberkorn U. ${ }^{68} \mathrm{Ga}$-labeled peptides in tumor imaging. J Nucl Med. 2005;46(suppl 1):172S-178S.

28. Atherton E. Fluorenylmethoxycarbonyl-Polyamide Solid Phase Peptide Synthesis: General Principles and Development. Oxford, U.K.: Oxford Information Press; 1989.

29. Reubi JC, Wenger S, Schmuckli-Maurer J, Schaer JC, Gugger M. Bombesin receptor subtypes in human cancers: detection with the universal radioligand ${ }^{125}$ I-[D-TYR(6), beta-ALA(11), PHE(13), NLE(14)] bombesin(6-14). Clin Cancer Res. 2002;8:1139-1146.

30. Azay J, Nagain C, Llinares M, et al. Comparative study of in vitro and in vivo activities of bombesin pseudopeptide analogs modified on the C-terminal dipeptide fragment. Peptides. 1998;19:57-63.

31. Accardo A, Mansi R, Morisco A, et al. Peptide modified nanocarriers for selective targeting of bombesin receptors. Mol Biosyst. 2010;6:878-887.

32. Kelly KA, Setlur SR, Ross R, et al. Detection of early prostate cancer using a hepsin-targeted imaging agent. Cancer Res. 2008;68:2286-2291.

33. Abiraj K, Mansi R, Tamma ML, et al. Tetraamine-derived bifunctional chelators for technetium-99m labelling: synthesis, bioconjugation and evaluation as targeted SPECT imaging probes for GRP-receptor-positive tumours. Chemistry. 16:2115-2124.

34. Zhang H. Design, Synthesis, and Preclinical Evaluation of Radiolabeled Bombesin Analogues for the Diagnosis and Targeted Radiotherapy of Bombesin Receptor Expressing Tumors [PhD thesis]. Basel, Switzerland: Basel University; 2007. http://edoc.unibas.ch/586/.

35. Garrison JC, Rold TL, Sieckman GL, et al. In vivo evaluation and small-animal $\mathrm{PET} / \mathrm{CT}$ of a prostate cancer mouse model using ${ }^{64} \mathrm{Cu}$ bombesin analogs: sideby-side comparison of the CB-TE2A and DOTA chelation systems. J Nucl Med. 2007;48:1327-1337. 